\title{
Substrate Inhibition of the Growth of Bacterium NCIB 8250 by Phenol
}

\author{
By G. L. JONES, F. JANSEN AND A. J. MCKAY \\ Water Pollution Research Laboratory of the Department \\ of the Environment, Stevenage, Hertfordshire
}

(Received 20 September 197I ; revised 13 September 1972)

\begin{abstract}
SUMMAR Y
Examination of the growth kinetics of Bacterium NCIB 8250 in a two-stage continuous culture showed that growth of this organism on phenol could be accounted for by the Haldane function for substrate inhibition. The magnitude of the constants $\left(K_{\mathrm{s}}<\mathrm{I} \mathrm{mg} / \mathrm{l}\right.$; and $K_{\mathrm{i}}$, Iro mg/l) was such that inhibition was the dominant factor governing the growth of the organism even at substrate concentrations less than $10 \mathrm{mg} / \mathrm{l}$. The maintenance requirement of the organism was high $(0.24$ to $0.28 \mathrm{~g} / \mathrm{g} \mathrm{h}$ ), probably owing to the energy requirement for rupture of the aromatic nucleus of the substrate.

The influence of such kinetics on the treatment of inhibitory wastes by the activated-sludge process is discussed. Extreme sensitivity of the experimental system to slight changes in operating conditions was explicable by a mathematical model using constants found in the investigations.
\end{abstract}

\section{INTRODUCTION}

As a step towards the elucidation of the biochemical and microbial interactions involved in the treatment of waste waters by the activated-sludge process, a study was made of some of the bacteria concerned in the treatment of carbonization waste liquors. This choice was made since the range of substrates available in this system is limited, and a simpler bacterial ecosystem was expected than in the case of sewage treatment. Of the ten strains isolated from a laboratory-scale plant treating a carbonization waste liquor, only two were capable of growth on phenol and were selected for further study.

One of these strains was identified as a member of the Acinetobacter-Moraxella group, very similar in properties to Bacterium NCIB 8250 (Sebald \& Véron, I963; Véron, I966; Fewson, 1967). When, during preliminary experiments, the original strain was lost, the work was continued with Bacterium NCIB 8250.

Operation of the activated-sludge process to produce a low substrate concentration in the effluent depends on settlement of the organisms leaving the reactor, and subsequent recycle of these organisms (thus reducing the specific growth rate to a value below the dilution rate of the system). The study of pure cultures under conditions obtaining in the activatedsludge process is made difficult by this need to concentrate the culture leaving the reactor to allow recycling. This difficulty was overcome by use of a two-stage continuous-culture apparatus, where culture from the first stage, operated as a normal chemostat, was pumped to the second stage, together with a supply of fresh medium. In this way the second stage was analogous to the reactor of an activated-sludge plant, with the specific growth rate of the organisms less than the dilution rate. 


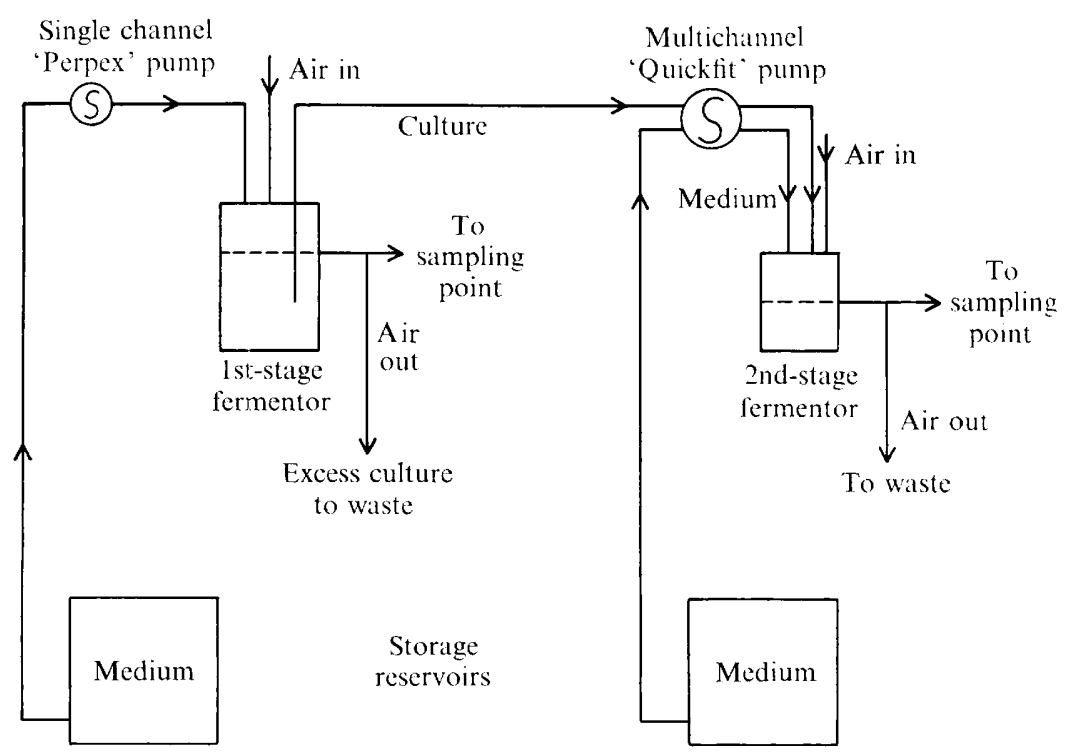

Fig. I. Flow diagram of two-stage continuous-culture apparatus.

\section{METHODS}

Organism. Bacterium NCIB 8250 was subcultured monthly and maintained on nutrient agar slopes stored at $5{ }^{\circ} \mathrm{C}$.

Medium. Constituents added ( $\mathrm{g} / \mathrm{l}$ deionized distilled water) were: $\mathrm{KH}_{2} \mathrm{PO}_{4}, 2 \cdot 0 ;\left(\mathrm{NH}_{4}\right)_{2}$ $\mathrm{SO}_{4}, \mathrm{I} \cdot 0 ; \mathrm{MgSO}_{4} \cdot 7 \mathrm{H}_{2} \mathrm{O}, 0.2$; phenol to required concentration, $\mathrm{pH}$ adjusted to 6.8 with $\mathrm{M}-\mathrm{NaOH}$. Medium was made in $\mathrm{I} 4 \mathrm{l}$ batches and sterilized by filtration through a Sartorius membrane filter (mean pore size, $0.2 \mu \mathrm{m}$; V. A. Howe \& Co Ltd.) and filter-sterilized ferric chloride solution added to give a concentration of $10 \mathrm{mg} / \mathrm{l}$.

Salts solution. In some experiments the ferric chloride was replaced by a salts solution containing ( $\mathrm{g} / \mathrm{l}$ deionized distilled water): $\mathrm{FeSO}_{4} \cdot{ }_{7} \mathrm{H}_{2} \mathrm{O}, 0.5 ; \mathrm{ZnSO}_{4} \cdot 7 \mathrm{H}_{2} \mathrm{O}, 0 . \mathrm{I}$; $\mathrm{MnSO}_{4} \cdot 4 \mathrm{H}_{2} \mathrm{O}, 0 \cdot \mathrm{I} ; \mathrm{CuSO}_{4} \cdot 5 \mathrm{H}_{2} \mathrm{O}, 0 \cdot \mathrm{I}$; $\mathrm{CaCl}_{2} .6 \mathrm{H}_{2} \mathrm{O}$, 0.5; di-sodium salt of EDTA, $3 \cdot 3$. Portions ( $\mathrm{IO} \mathrm{ml}$ ) were added to each litre of medium.

Apparatus. The two-stage continuous culture apparatus (Fig. I) consisted of two 'Quickfit' culture vessels (FV I L and FV 500) fitted with multi-socket flat-flanged lids (MAF 2/2 and MAF I/75). (Jobling Laboratory Division, Stone, Staffordshire). Each fermentor was aerated by a diffuser ( $\mathrm{I}$ vol. of sterile air/vol. of culture/min) and stirred by a Teflon-covered magnet. The operating volume of the vessels could be adjusted by changing the level of the overflow. Each overflow was fitted with a sampling device similar to those used by Curds \& Cockburn (I97I), modified to take I oz screw-cap bottles. Connexions between the fermentors and medium reservoirs were made with silicone-rubber tubing and the whole apparatus was sterilized by autoclaving at $105 \mathrm{kN} / \mathrm{m}^{2}$ for $\mathrm{I} \mathrm{h}$.

Sterile medium was pumped continuously from a 201 storage reservoir to the first-stage fermentor by means of a fixed-speed 'Perpex' peristaltic pump (LKB Instruments Ltd, South Croydon, Surrey). Some of the culture from the first stage was pumped continuously through one or more channels of a 'Quickfit' six-channel variable speed peristaltic pump to the second stage, the remainder of the effluent from the first stage being discharged to waste. In addition to culture from the first stage, a continuous supply of fresh medium was pumped from another 
201 storage reservoir to the second stage through one or more of the remaining channels of the 'Quickfit' pump. By changing the number of channels used for each stream, or by using pump tubes with different internal diameters, the concentrations of micro-organism and substrate entering the second stage could be adjusted. The apparatus was maintained at $20 \pm 0.5{ }^{\circ} \mathrm{C}$ in a water bath.

Analyses. Phenol was determined by the 4-amino phenazone method of Ochynski (I960).

Bacterial concentration. The bacterial dry weight was determined by filtration of $10 \mathrm{ml}$ of sample through a washed $(2 \times 10 \mathrm{ml}$ membrane-filtered water $)$ and dried Oxoid membrane filter. The sample was then washed with $2 \times 5 \mathrm{ml}$ membrane-filtered water, and dried at I0 ${ }^{\circ} \mathrm{C}$ for $\mathrm{I} h$. The membranes were weighed before and after the two drying periods with a similarly treated membrane as tare, through which $10 \mathrm{ml}$ of membrane-filtered water was passed in place of the sample.

\section{RESULTS}

The first-stage fermentor was operated at a constant dilution rate to provide a source of bacteria for the second stage. The second stage was operated over a range of dilution rates and it was assumed that steady states had been reached when there had been a minimum of three vol. changes during which bacterial and substrate concentrations did not change significantly. Concentrations of bacteria and substrate entering the second stage were calculated from the concentrations in the first stage and in the medium reservoir and the flow rates. Thus

$$
\text { bacterial concentration entering second stage }=x_{02}=\frac{f_{12} x_{1}}{f_{02}+f_{12}},
$$

where $f_{12}$ is the rate of flow of culture from first to second stage $(\mathrm{ml} / \mathrm{h}), f_{02}$ is the rate of flow of fresh medium to the second stage $(\mathrm{ml} / \mathrm{h})$, and $x_{1}$ is the concentration of bacteria in the first stage $(\mathrm{mg} / \mathrm{l})$.

$$
\text { Substrate concentration entering second stage }=s_{02}=\frac{f_{02} s}{f_{12}+f_{02}}
$$

where $s$ is the concentration of substrate in the fresh medium supplied to the second stage $(\mathrm{mg} / \mathrm{l})$. (Since the concentration of substrate leaving the first stage was below the detectable limit of $\mathrm{I} \mathrm{mg} / \mathrm{l}$, it was not necessary to make allowance for substrate in this flow when calculating the concentration entering the second stage.)

With a second-stage culture volume of $v_{2}$, the dilution rate of the second stage $D_{2}\left(\mathrm{~h}^{-1}\right)$ was given by $\left(f_{12}+f_{02}\right) / v_{2}$ and the specific growth rate of the culture in the second stage could then be determined from the relationship

$$
\mu_{2}=D_{2} \frac{x_{2}-x_{02}}{x_{2}}
$$

where $\mu_{2}$ is the specific growth rate $\left(\mathrm{h}^{-1}\right)$ and $x_{2}$ is the bacterial concentration in the second stage $(\mathrm{mg} / \mathrm{l})$.

The concentration of bacteria entering the second stage was maintained in the range 40 to $70 \mathrm{mg} / \mathrm{l}$ (nominal value $52 \mathrm{mg} / \mathrm{l}$ ) and substrate concentration in the range 226 to $236 \mathrm{mg} / \mathrm{l}$ (nominal value $229 \mathrm{mg} / \mathrm{l}$ ). Variations in these values were caused by changes in the pumping rate of the two channels in the Quickfit pump and by some growth which occurred on the walls of the first stage fermentor from time to time. Below a dilution rate of $0.37 \mathrm{~h}^{-1}$ in the second stage the culture remained stable, and substrate could not be detected; in the range 0.37 to $0.44 \mathrm{~h}^{-1}$ the culture became more susceptible to variations in input bacterial concentration, which could cause the substrate concentration to switch between being 
Table I. Yield constants $\left(Y_{2}\right)$ found for second-stage fermentor operated at various dilution rates $\left(D_{2}\right)$ during substrate-inhibited growth of Bacterium NCIB 8250 on phenol $\left(s_{2}>\sqrt{ }\left(K_{1} K_{8}\right)\right)$

Organisms and substrate are entering at flow rates $f_{12}$ and $f_{02}$ and concentrations $x_{1}$ and $s_{02}$ and leaving at concentrations $x_{2}$ and $s_{2}$. First-stage dilution rate $D_{1}, 0 \cdot 12 \mathrm{~h}^{-1}$; substrate concentration entering first stage $s_{01}, 365 \mathrm{mg} / \mathrm{l}$; volume of first stage, $700 \mathrm{ml}$; volume of second stage, $200 \mathrm{ml}$.

\begin{tabular}{|c|c|c|c|c|c|c|c|}
\hline $\begin{array}{c}x_{1} \\
(\mathrm{mg} / \mathrm{l})\end{array}$ & $\begin{array}{c}f_{12} \\
(\mathrm{ml} / \mathrm{h})\end{array}$ & $\underset{(\mathrm{ml} / \mathrm{h})}{f_{02}}$ & $\begin{array}{c}D_{2} \\
\left(\mathrm{~h}^{-1}\right)\end{array}$ & $\begin{array}{c}s_{02} \\
(\mathrm{mg} / \mathrm{l})\end{array}$ & $\begin{array}{c}x_{2} \\
(\mathrm{mg} / \mathrm{l})\end{array}$ & $\begin{array}{c}s_{2} \\
(\mathrm{mg} / \mathrm{l})\end{array}$ & $Y_{2}$ \\
\hline 129 & 19 & 24 & 0.22 & 225 & 148 & $<\mathrm{I}$ & 0.41 \\
\hline I I 5 & 39 & $5 \mathrm{I}$ & 0.45 & 228 & 67 & I 54 & 0.24 \\
\hline I I I & 39 & $5 \mathrm{I}$ & 0.45 & 228 & 68 & I 53 & 0.27 \\
\hline 126 & 37 & 50 & 0.435 & $23 \mathrm{I}$ & I 44 & 10 & 0.39 \\
\hline 162 & 37 & 50 & 0.435 & $23 \mathrm{I}$ & I 45 & 23 & 0.37 \\
\hline 142 & 37 & 50 & 0.435 & $23 \mathrm{I}$ & I 24 & 37 & 0.33 \\
\hline 130 & 38 & $5 \mathrm{I}$ & 0.445 & 231 & 76 & 167 & 0.33 \\
\hline 124 & 38 & $5 \mathrm{I}$ & 0.445 & $23 I$ & 70 & 160 & 0.25 \\
\hline 103 & 30 & 44 & 0.37 & - & 67 & 95 & - \\
\hline 98 & 29 & 43 & 0.36 & - & 185 & $<\mathrm{I}$ & - \\
\hline $9 \mathrm{I}$ & 29 & 44 & 0.365 & - & 72 & 74 & - \\
\hline
\end{tabular}

undetectable and a high value. With bacterial and substrate concentrations maintained at the nominal values a dilution rate of $0.44 \mathrm{~h}^{-1}$ was critical, below this value substrate was not detectable but an increase from 0.44 to $0.45 \mathrm{~h}^{-1}$ caused an abrupt increase from Io to I $50 \mathrm{mg} / \mathrm{l}$.

\section{Growth rate}

Steady-state specific growth rate and substrate concentration (Table I) were plotted according to the Haldane (I930) function, which takes the form

$$
\mu_{s}=\frac{\mu_{\max }}{\mathrm{I}+K_{\mathrm{s}} / s+s / K_{\mathrm{i}}}
$$

where $\mu_{\max }$ is the maximum growth rate in the absence of inhibition; $s$ is the steady state substrate concentration $(\mathrm{mg} / \mathrm{l}) ; K_{\mathrm{s}}$ is the saturation constant, the lowest substrate concentration (mg/l) at which, in the absence of inhibition, the specific growth rate is half the maximum growth rate $\left(\mu_{\max }\right)$; and $K_{\mathrm{i}}$ is the inhibition constant, which numerically equals the highest substrate concentration $(\mathrm{mg} / \mathrm{l})$ at which the specific growth rate is equal to one half the maximum specific growth rate $\left(\mu_{\text {max }}\right)$.

At high substrate concentrations, if $K_{\mathrm{s}}$ is small, $K_{\mathrm{s}} / s$ is negligible so that in the reciprocal form equation (2) reduces to

$$
\frac{\mathrm{I}}{\mu}=\frac{\mathrm{I}}{\mu_{\max }}+\frac{s}{\mu_{\max } K_{\mathrm{i}}}
$$

and a plot of $\mathrm{I} / \mu$ against $s$ gives a straight line (Fig. 2) with intercepts of $\mathrm{I} / \mu_{\max }$ and $K_{1}$. From Fig. 2, values of $0.29 \mathrm{~h}^{-1}$ and I IO mg/l were obtained for $\mu_{\max }$ and $K_{\mathrm{i}}$ respectively.

\section{Morphological changes}

The microscopic appearance of the organism was observed to change with cultural conditions. When the inhibition constant dominated the growth rate, the cells appeared more rod-like and some filamentous forms were seen. When cultural conditions were returned to those where the saturation constant was dominant the normal cocco-bacillus form reappeared 


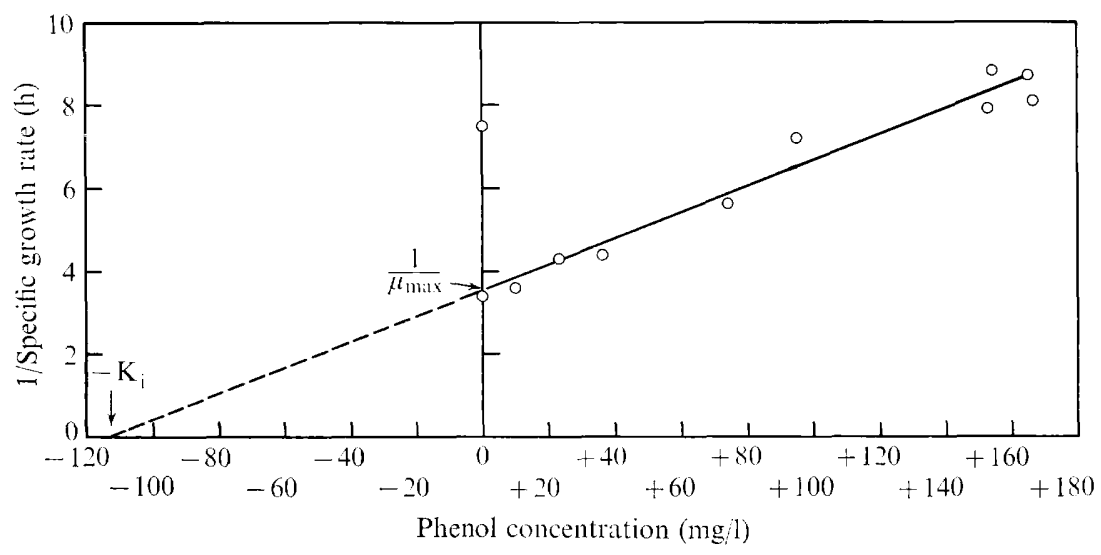

Fig. 2. Substrate inhibition of Bacterium NCIB 8250 growing on phenol. Points on vertical axis were obtained at substrate concentrations below detection limit of phenol.

\section{Saturation constant}

A precise evaluation of the saturation constant for this organism growing on phenol was not possible. Since the relationship is still linear at low substrate concentrations (Fig. 2), the saturation constant must also be low. Differentiation of the Haldane equation shows that the maximum attainable growth rate occurs at a substrate concentration given by $\sqrt{ }\left(K_{\mathrm{i}} K_{\mathrm{s}}\right)$, which is clearly below $10 \mathrm{mg} / \mathrm{l}$, so that the value of $K_{\mathrm{g}}$ must be less than $\mathrm{IO}^{2} / K_{\mathrm{i}}$, i.e. approx. $0.9 \mathrm{mg} / \mathrm{l}$.

The detection limit of the 4-amino phenazone test for phenol is about $\mathrm{I} \mathrm{mg} / \mathrm{l}$ and, unless the culture was showing inhibition, phenol could not be detected in the effluent even at growth rates in excess of $\mu_{\max } / 2$, again showing that $K_{\mathrm{s}}$ was less than I mg/1.

\section{Yield and maintenance requirement}

In addition to the decrease in growth rate with increasing substrate concentration, the yield of organisms also decreased. To explain such a decrease in yield with reduction of growth rate, Pirt (1965) proposed the relationship

$$
\frac{\mathrm{I}}{Y}=\frac{\mathrm{I}}{Y_{\mathrm{G}}}+\frac{m}{\mu}
$$

where $Y$ is the observed growth yield, $Y_{\mathrm{G}}$ is the 'true' growth yield, i.e. the yield that would be obtained in the absence of a maintenance requirement, and $m$ is the maintenance coefficient (g substrate/g dry wt $h$ ).

Plotting observed values of $\mathrm{I} / Y$ against $\mathrm{I} / \mu$ for specific growth rates in the range $0 . \mathrm{I}$ I to $0.28 \mathrm{~h}^{-1}$ gave a straight line $(\mathrm{I} / Y=(0 \cdot 28 / \mu)+\mathrm{I} \cdot 7)$ and values of $0.59 \mathrm{~g} / \mathrm{g}$ and $0.28 \mathrm{~g} / \mathrm{g} \mathrm{h}$ for $Y_{\mathrm{\sigma}}$ and $m$ respectively (Fig. $3 a$ ).

Further experiments were carried out to examine changes in yield with specific growth rate under 'non-inhibitory' conditions, i.e. when specific growth rate theoretically increases with substrate concentration or $s_{2}<\sqrt{ }\left(K_{1} K_{8}\right)$. Unfortunately at this time the supply arrangements for the de-ionized distilled water were changed, and using water from the new supply the medium described would not reliably support growth. By replacing the ferric chloride by the 'salts solution' containing trace metals the organism grew readily, and the experiments were continued using this medium.

At high substrate concentrations it was difficult to obtain steady states owing to a ten- 


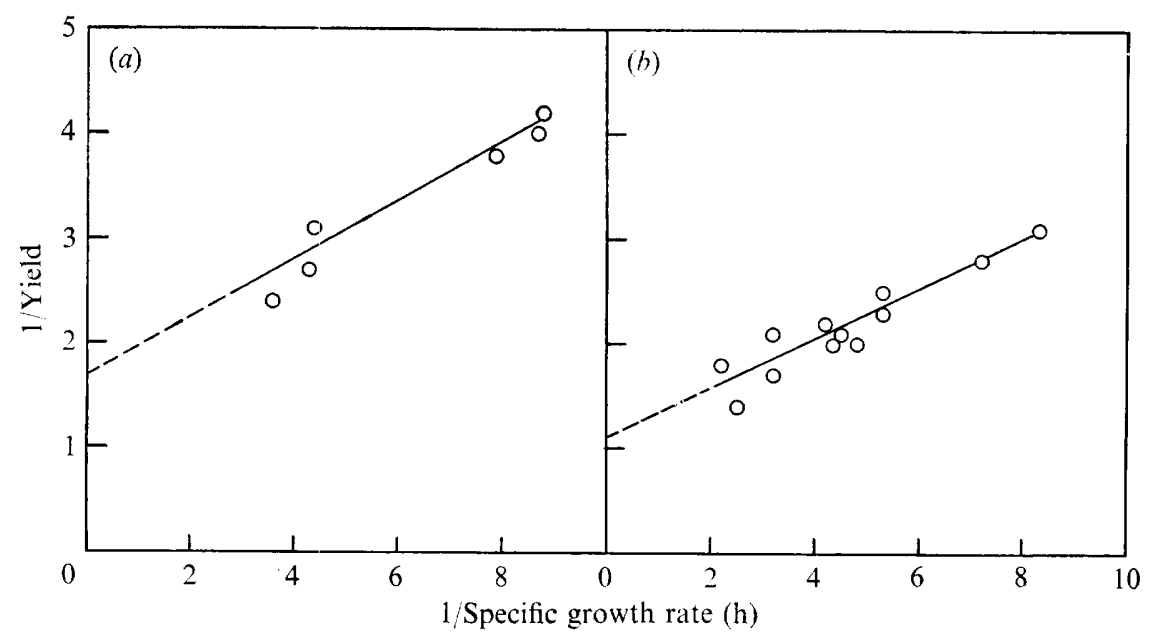

Fig. 3. Change in yield with growth rate of Bacterium NCIB 8250 growing on phenol under

(a) inhibitory conditions $\left(s_{2}>\sqrt{ }\left(K_{\mathrm{i}} K_{\mathrm{s}}\right)\right)$ and $(b)$ non-inhibitory conditions $\left(s_{2}<\sqrt{ }\left(K_{\mathrm{i}} K_{\mathrm{s}}\right)\right)$.

Table 2. Yield constants $\left(Y_{2}\right)$ found for second-stage fermentor operated at various dilution rates $\left(D_{2}\right)$ during 'non-inhibited' growth of Bacterium NCIB 8250 on phenol $\left(s_{2} \sqrt{ }\left(K_{1} K_{\mathrm{g}}\right)\right)$

Organisms and substrate are entering at flow rates $f_{12}$ and $f_{02}$ and concentrations $x_{1}$ and $s_{02}$ and leaving at concentrations $x_{2}$ and $s_{2}$. First-stage dilution rate $D_{1}$, substrate concentration entering first stage $s_{01}$, and cell concentration in first stage $x_{1}$ shown for each group of experiments. Volume of first stage, $760 \mathrm{ml}$; volume of second stage, $250 \mathrm{ml}$.

\begin{tabular}{|c|c|c|c|c|c|c|c|c|}
\hline & & $\begin{array}{c}f_{12} \\
(\mathrm{ml} / \mathrm{h})\end{array}$ & $\begin{array}{c}f_{02} \\
(\mathrm{ml} / \mathrm{h})\end{array}$ & $\begin{array}{c}D_{2} \\
\left(\mathrm{~h}^{-1}\right)\end{array}$ & $\begin{array}{c}s_{02} \\
(\mathrm{mg} / \mathrm{l})\end{array}$ & $\begin{array}{c}x_{2} \\
(\mathrm{mg} / \mathrm{l})\end{array}$ & $\begin{array}{c}s_{2} \\
(\mathrm{mg} / \mathrm{l})\end{array}$ & $Y_{2}$ \\
\hline & $D_{1}=0.12 \mathrm{~h}^{-1}$ & $10 \cdot 8$ & $28 \cdot 5$ & $0 \cdot 16$ & 254 & I I 2 & $<\mathrm{I}$ & 0.32 \\
\hline & $s_{01}=362 \mathrm{mg} / 1$ & I $3 \cdot 4$ & $34 \cdot 2$ & 0.19 & 252 & 122 & $<\mathrm{I}$ & $0 \cdot 36$ \\
\hline & $x_{1}=\mathrm{I} / 2 \mathrm{mg} / \mathrm{l}$ & $16 \cdot 2$ & $43 \cdot I$ & 0.24 & 255 & I 44 & $<\mathrm{I}$ & 0.44 \\
\hline & & 19.4 & 50 & 0.28 & 252 & 152 & $<1$ & 0.48 \\
\hline & & 22 & 55 & $c \cdot 32$ & $25 \mathrm{I}$ & 145 & $<\mathbf{I}$ & 0.45 \\
\hline \multirow{4}{*}{ (b) } & $D_{1}=0.12 \mathrm{~h}^{-1}$ & $25 \cdot 3$ & 57 & 0.33 & 243 & 172 & $<\mathbf{I}$ & 0.5 \\
\hline & $s_{01}=384 \mathrm{mg} / \mathrm{l}$ & $32 \cdot 4$ & $76 \cdot 7$ & $0 \cdot 44$ & 246 & I 66 & $<\mathrm{I}$ & 0.47 \\
\hline & $x_{1}=\mathrm{I} 65 \mathrm{mg} / \mathrm{l}$ & $30 \cdot 3$ & $74 \cdot I$ & 0.42 & 249 & 188 & $<\mathrm{I}$ & 0.6 \\
\hline & & $37 \cdot 9$ & $89 \cdot 6$ & $0.5 \mathrm{I}$ & 246 & $22 \mathrm{I}$ & $<\mathrm{I}$ & 0.7 \\
\hline (c) & $\left.\begin{array}{l}s_{01}=350 \mathrm{mg} / 1 \\
x_{1}=136 \mathrm{mg} / 1\end{array}\right\}$ & $38 \cdot 6$ & $97 \cdot 9$ & 0.54 & 362 & 247 & $<\mathbf{I}$ & 0.57 \\
\hline \multirow{2}{*}{$(d)$} & $D_{1}=0.14 \mathrm{~h}^{-1}$ & $32 \cdot 5$ & $4 I \cdot 5$ & 0.3 & 322 & 209 & $<$ I & 0.4 \\
\hline & $\begin{array}{l}s_{01}=388 \mathrm{mg} / \mathrm{l} \\
x_{1}=179\end{array}$ & $35 \cdot 3$ & $42 \cdot 6$ & $0 \cdot 3 \mathrm{I}$ & 314 & 239 & $<$ I & 0.5 \\
\hline
\end{tabular}

dency for the culture to grow on the wall of the reactor and in the overflow. However, results were qualitatively the same, with a decrease in specific growth rate at high substrate concentrations. Under non-inhibitory conditions no difficulties were experienced with wall growth, and specific growth rates and yields were determined over a range of dilution rates from 0.16 to $0.54 \mathrm{~h}^{-1}$ (Table 2); their reciprocals are plotted in Fig. $3(b)$, which gave values for the 'true' growth yield and maintenance coefficient of $0.9 \mathrm{~g} / \mathrm{g}$ and $0.24 \mathrm{~g} / \mathrm{g} \mathrm{h}$ respectively. 


\section{DISCUSSION}

The occurrence of substrate inhibition in the growth of Bacterium NCIB 8250 has been described previously by Kennedy \& Fewson (I968), who showed that during growth in batch culture on certain aromatic substrates the specific growth rate decreased with increasing substrate concentration. Our results show that growth of this organism on phenol was substrate inhibited and could be described by the Haldane function which has been used extensively in enzymology. While there may be no theoretical justification for using this function to describe bacterial growth kinetics as well as enzyme kinetics, Andrews (1968) pointed out that the widely used Monod relationship is similar in form to the MichaelisMenten expression on which the function is based. Additionally, Boon \& Laudelout (1962) showed that the function could be used to fit the behaviour of Nitrobacter winogradskyi using nitrite as substrate.

\section{Stability of the system}

Spicer (1955) in a theoretical study of continuous-culture systems showed that a stable equilibrium could only occur when $\mathrm{d} \mu / \mathrm{d} s>0$. In the case of substrate inhibition such a criterion cannot be met when $s>\sqrt{ }\left(K_{\mathrm{i}} K_{\mathrm{s}}\right)$, so that instability will occur. Both Andrews (I968) and Yano \& Koga (1969) examined this instability with mathematical models based on the Haldane equation for substrate inhibition. Yano \& Koga (1969) described the existence of three non-negative steady states, of which two were stable and the third unstable. The two stable steady states were the normal condition of high cell concentration and low substrate concentration and that which they called the wash-out steady state. In a two-stage continuous-culture system, because of the continuous supply of organisms to the second stage, wash out cannot occur, and the wash-out steady state of Yano \& Koga (I969) will correspond to a condition of high substrate and low cell concentration. The steady states obtained at high and low dilution rates correspond to the stable steady states, and the unstable steady state $\left(\mathrm{d} \mu / \mathrm{d} s_{02}<0\right)$ lies in the region where the culture was susceptible to fluctuations in the input bacterial concentrations.

Increase in bacterial concentrations in the second stage is given by

$$
x_{2}-x_{02}=Y\left(s_{02}-s_{2}\right) \text {. }
$$

By applying equations (I), (2), (4) and (5) to the second-stage fermentor, and eliminating $x_{2}$ and $Y$, is can be shown that

$$
D_{2}=\frac{\mu_{\max }}{\mathrm{I}+K_{s} / s_{2}+s_{2} / K_{\mathrm{i}}}\left[\frac{x_{02}}{Y_{\mathrm{G}}\left(s_{02}-s_{2}\right)}+\mathrm{I}\right]+\frac{x_{02} m}{s_{02}-s_{2}} .
$$

Solution of this equation for $D$ over a range of values for $s_{2}$ at constant $x_{02}$ and $s_{02}$ produces a hysteresis curve as shown in Fig. 4. The upper (C-D) and lower (A-B) parts of the hysteresis curve correspond to two stable steady states, while the intermediate values of substrate concentration (B-C) correspond to an unstable steady state (Edelstein, 1970).

Using the constants obtained from the data (assuming $K_{s}=0.1 \mathrm{mg} / \mathrm{l}$ ) and values for $x_{02}$ and $s_{02}$ of 52 and $229 \mathrm{mg} / \mathrm{l}$ respectively, the curve is consistent with the observed behaviour of the culture in the second stage. Thus when the dilution rate was increased from 0.44 to $0.45 \mathrm{~h}^{-1}$, the abrupt increase in substrate concentration represented a change between two stable steady states. The overlap of the two stable states could explain the tendency for the substrate concentration to wander with variations of incoming cell and substrate concentration, as was found in the dilution rate range $0.37-0.44 \mathrm{~h}^{-1}$. Outside this range of dilution rates the system would be stable since at each extreme there exists only one positive steadystate solution. 


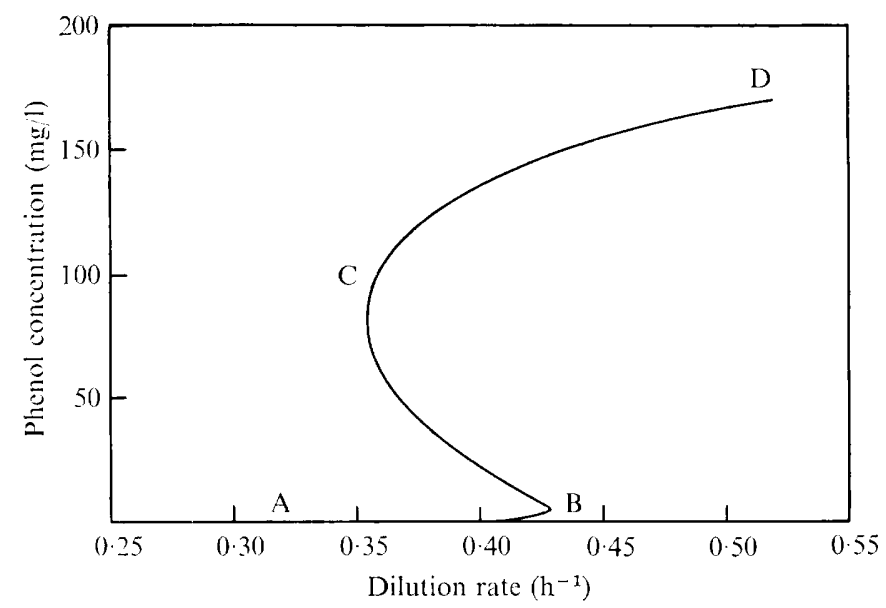

Fig. 4. Relationship between substrate concentration and dilution rate in second stage of a twostage continuous culture growing on an inhibitory substrate. $K_{8}=0 \cdot 1 \mathrm{mg} / \mathrm{l}, K_{\mathrm{i}}=\mathrm{I} 10 \mathrm{mg} / \mathrm{l}$, $s_{02}=229 \mathrm{mg} / \mathrm{l}, x_{02}=52 \mathrm{mg} / \mathrm{l}$ (for explanation of points A, B, C, and D see text).

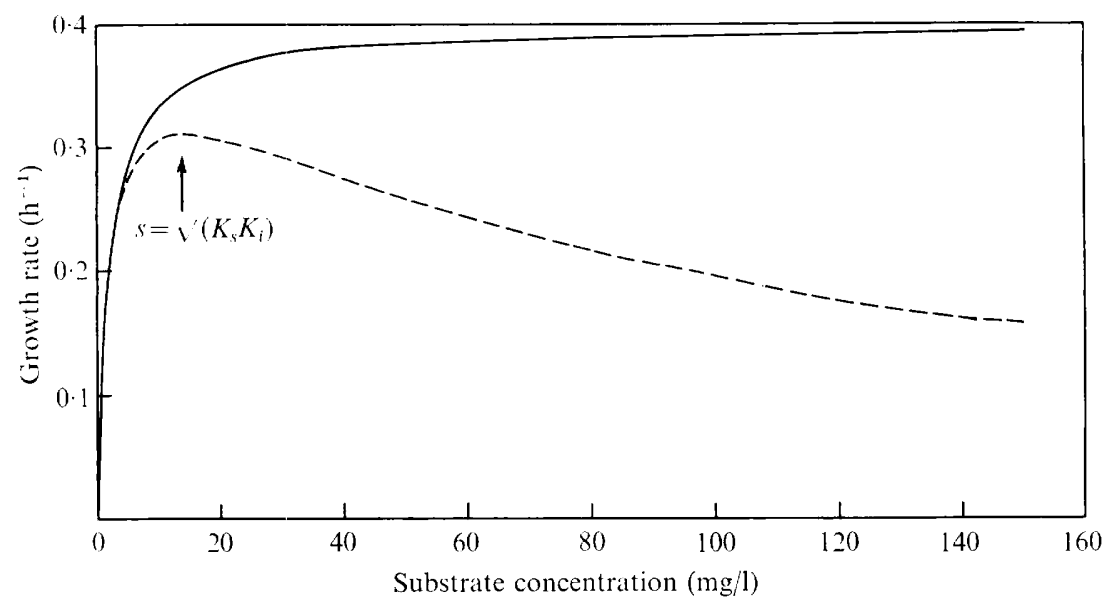

Fig. 5. Comparison of theoretical curves for normal (solid line) and substrate inhibited (broken line) growth with values of $K_{\mathrm{s}}=2 \mathrm{mg} / \mathrm{l}, \mu_{\mathrm{m}}=0.4 \mathrm{~h}^{-1}$ and $K_{\mathrm{i}}=100 \mathrm{mg} / \mathrm{l}$.

\section{Maintenance coefficients}

The values obtained for the maintenance coefficient of Bacterium NCIB 8250 growing aerobically on phenol $(0.24$ and $0.28 \mathrm{~g} / \mathrm{g} \mathrm{h})$ were considerably higher than those quoted by Pirt (1965) for aerobic growth of Aerobacter aerogenes on glycerol ( $m=0.076 \mathrm{~g} / \mathrm{g} \mathrm{h}$ ) and $A$. cloacae on glucose $(m=0.094 \mathrm{~g} / \mathrm{g} \mathrm{h})$. Such a difference might be expected since growth of an organism on phenol requires the cleavage of the aromatic nucleus needing a considerable expenditure of energy.

The maintenance coefficients obtained for 'inhibited' and 'non-inhibited' growth were not strictly comparable since different media had to be used in the two series of experiments. However, the two values obtained were of the same order and it is possible that the maintenance requirements for the two states are not very different, particularly when compared with the energy required for the disruption of the aromatic nucleus. 


\section{Yield coefficients}

Yields of organisms growing on an aromatic substrate are high when expressed as $\mathrm{g}$ bacteria/g substrate, which may be accounted for by the high carbon content of the substrate. The highest observed yield was $0 \cdot 72$, or $67 \cdot 7 \mathrm{~g} / \mathrm{mol}$ of substrate, which is within the range ( 50 to 72 ) of values given by Kennedy \& Fewson (I 968) for growth of this organism on other aromatic substrates.

\section{Practical implications}

Treatment of wastes containing inhibitory substrates is often necessary, and the question of stability is of considerable importance if the substrate concentration in the effluent is to be as low as possible. The main property of substrate inhibition kinetics is that for each specific growth rate below the maximum attainable growth rate there are two possible steady-state substrate concentrations (Fig. 5). Under normal conditions a completely mixed treatment plant should operate in the region below inhibition at values of $s$ below $\sqrt{ }\left(K_{\mathrm{s}} K_{\mathrm{s}}\right)$, but under certain conditions, e.g. start-up, organism recycle failure, or an increase in flow rate, the system could be driven into a situation where $K_{\mathrm{i}}$ becomes dominant, $s$ is greater than $\sqrt{ }\left(K_{\mathrm{i}} K_{\mathrm{s}}\right)$, and wash out ensues.

In such a system the limiting specific growth rate will be that obtained when the substrate concentration in the reactor is equal to that in the influent, i.e. $\mu=\mu_{\max } /\left(\mathrm{I}+K_{\mathrm{s}} / s_{02}+s_{02} / K_{\mathrm{i}}\right)$. For an organism to be maintained within an activated-sludge system, the growth rate must be able to exceed that given by the relationship

$$
\mu=D[\mathrm{I}-a(b-\mathrm{I})],
$$

where $a$ is the recycle ratio (flow of recycle/flow of influent) and $b$ is the concentration ratio (concentration of cells in recycle/concentration of cells in reactor). Thus, in the case of an organism exhibiting substrate inhibition, provided that $\mu_{\max } /\left(\mathrm{I}+K_{s} / s_{02}+s_{02} / K_{\mathrm{i}}\right)>$ $D[\mathrm{I}-a(b-\mathrm{I})]$ the system will remain stable and wash out cannot occur.

Crown copyright. Reproduced by permission of the Controller, H.M. Stationery Office. F.J. is a voluntary worker from Laboratorium voor Microbiologie der Landbouwhogschool, Wageningen, and A.J.M. a college based sandwich-course student from Chelsea College of Science and Technology.

\section{REFERENCES}

ANDrEws, J. F. (1968). A mathematical model for the continuous culture of microorganisms utilising inhibitory substrates. Biotechnology and Bioengineering ro, 707-723.

Boon, B. \& Laudelout, H. (1962). Kinetics of nitrite oxidation by Nitrobacter winogradskyi. Biochemical Journal $85,440-447$.

Curds, C. R. \& CockBurn, A. (1971). Continuous monoxenic culture of Tetrahymena pyriformis. Journal of General Microbiology 66, 95-108.

Edelstern, B. B. (I970). Biochemical model with multiple steady states and hysteresis. Journal of Theoretical Biology 29, 57-62.

Fewson, C. A. (1967). The identity of the Gram-negative Bacterium NCIB 8250 ('Vibrio oI'). Journal of General Microbiology 48, 107-1 10.

Haldane, J. B. S. (1930). Enzymes. London: Longmans.

Kennedy, S. I. T. \& Fewson, C. A. (I968). Metabolism of mandelate and related compounds by Bacterium NCIB 8250. Journal of General Microbiology 53, 259-273.

Ochynski, F. W. (i 960). The absorptiometric determination of phenol. Analyst 85, 278-28I.

PIRT, S. J. (I 965). The maintenance energy of bacteria in growing cultures. Proceedings of the Royal Society B I63, 224-231. 
Sebald, M. \& Véron, M. (1963). Teneur en bases de l'ADN et classification des Vibrions. Annales de l'Institut Pasteur 105, 897.

SPICER, C. C. (1955). The theory of bacterial constant growth apparatus. Biometrics II, 225-230.

VÉron, M. (I966). Taxonomie numérique des vibrions et de certaines bactéries comparables. II. Correlation entre les similitudes phenotiques et la composition en bases de l'ADN. Annales de l'Institut Pasteur IIr, 67 I.

Yano, T. \& KogA, S. (1969). Dynamic behaviour of the chemostat subject to substrate inhibition. Biotechnology and Bioengineering II, I39-153. 